\title{
Grapevine varieties exhibiting differences in stomatal response to water deficit
}

\author{
Joaquim M. Costa ${ }^{\mathrm{A}, \mathrm{B}, \mathrm{D}, \mathrm{E}}$, Maria F. Ortuño ${ }^{\mathrm{B}, \mathrm{C}, \mathrm{D}}$, Carlos M. Lopes $^{\mathrm{A}}$ and Maria M. Chaves $^{\mathrm{A}, \mathrm{B}}$

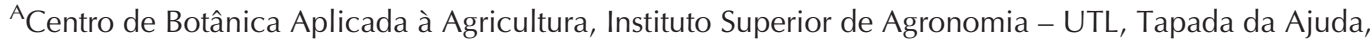 \\ 1349-017 Lisboa, Portugal. \\ B Laboratório de Ecofisiologia Molecular, Instituto de Tecnologia Química e Biológica -UNL, Apartado 127, \\ 2780-901 Oeiras, Portugal. \\ CPresent address: Centro de Edafologia y Biologia Aplicada del Segura (CEBAS-CSIC), PO Box 164, \\ 30100 Murcia, Spain. \\ DThese authors contributed equally to this work. \\ ${ }^{\mathrm{E}}$ Corresponding author. Email: miguelc@itqb.unl.pt
}

\begin{abstract}
Knowledge on variety traits and physiological responses to stress is still scarce in Vitis vinifera L., limiting the optimisation of irrigation and breeding for high water use efficiency. We have characterised five grapevine varieties using thermal imaging, leaf gas exchange, leaf morphology and carbon isotope composition. Plants of the varieties Aragonez, Trincadeira, Cabernet Sauvignon, Syrah and Touriga Nacional were grown in field conditions. Two experiments were performed. In Experiment I (2006), vines of Aragonez and Trincadeira were either well irrigated (WI, $80 \% E T_{\mathrm{c}}$ ), nonirrigated but rain fed (NI) or subjected to regulated deficit irrigation (RDI, $40 \% E T_{\mathrm{c}}$ ) and studied along the summer season. In Experiment II (2006 and 2007), vines of the five varieties were subjected to RDI (30-40\%ET $)$ and studied at veraison. In Experiment I, leaf temperature $\left(T_{\text {leaf }}\right)$ correlated negatively with stomatal conductance $\left(g_{\mathrm{s}}\right)$ and leaf water potential $\left(\Psi_{\mathrm{pd}}\right)$. The inverse relationship between $g_{\mathrm{s}}$ and $T_{\text {leaf }}$ was highly significant in the afternoon. In Experiment II, the different genotypes showed different $T_{\text {leaf }}$ for similar $\Psi_{\mathrm{pd}}$. Stomatal density did not correlate with $g_{\mathrm{s}}$ suggesting that varieties have different stomatal control. Our results show that combined measurements of canopy temperature and $\Psi_{\text {pd }}$ can aid in better understanding of stomatal regulation in different grapevine varieties. Such variation in stomatal regulation should be taken into account in determining irrigation strategies.
\end{abstract}

Additional keywords: genotypes, stomatal conductance to water vapour, thermal imaging, Vitis vinifera, water stress.

Received 15 July 2011, accepted 17 January 2012, published online 2 March 2012

\section{Introduction}

Vitis vinifera L. has a large genetic variability, with several thousands of varieties having been cultivated worldwide (Schultz and Stoll 2010). The species is generally considered as 'drought avoiding' and is well adapted to the Mediterranean climate (Schultz 2003; Schultz and Stoll 2010). However, the combination of soil water deficit, high vapour pressure deficit (VPD), high light intensities and high temperature during the summer decreases growth and yield with potential negative impact on berry quality (Chaves and Rodrigues 1987; Escalona et al. 1999; Flexas et al. 2002; Chaves et al. 2007, 2010; Flexas et al. 2010). Moreover, the large genetic heterogeneity of the species results in differences in the responses of varieties to drought, namely in terms of their leaf stomatal response (iso and anisohydric behaviour), photosynthetic assimilation and water use efficiency (Chaves et al. 1987, 2010; Bota et al. 2001; Medrano et al. 2003; Flexas et al. 2010). It also represents an opportunity for breeding for more efficient vines regarding water use; this is particularly important in the context of scarce water resources, where the use of water saving strategies (deficit irrigation) in irrigated viticulture is required.

Growers need to optimise deficit irrigation strategies to guarantee a proper balance between vegetative growth and fruit load, and minimise negative effects of the imposed mild stress (Cifre et al. 2005; Girona et al. 2006; Costa et al. 2007). Assessment of plant water status and canopy temperature is a relevant approach to decide when and how much irrigation is required.

In recent decades, several imaging technologies were developed enabling the study of plant stress physiology remotely and non-destructively (Nilsson 1995; Chaerle and van der Straeten 2000; Jones 2004). Among them, thermal imaging has emerged as one of the most useful, being widely used in industry and in science (Kaplan 2007). In plant science, thermal imaging has become a feasible approach to measure the temperature of plants and indirectly assess leaf transpiration and plant water status. When stomata close, leaf transpiration 
is reduced, leading to higher leaf temperatures as compared with leaves with open stomata (Jones 1999; Jones et al. 2002; Araus et al. 2008).

Thermal imaging has been used to screen genotypes with different stomatal conductance not only for the model plant Arabidopsis thaliana (L.) Heynh. (Merlot et al. 2002, 2007) but also for crops like wheat (Raskin and Ladyman 1988; James et al. 2008), chickpea (Kashiwagi et al. 2008), rice (Hirayama et al. 2006), barley (Sirault et al. 2009) and more recently, strawberry (Grant et al. 2012). Different studies have shown the feasibility of thermal imaging as a tool to monitor water stress and support irrigation scheduling of relevant crops like grapevine (Jones et al. 2002; Grant et al. 2006, 2007; Möller et al. 2007), cotton (Alchanatis et al. 2010), olive trees (Ben-Gal et al. 2009) and citrus (García-Tejero et al. 2011). However, screening varieties of grapevine showing different leaf temperature has not been explored.

The major aims of our study were to characterise the transpirational behaviour of different $V$. vinifera genotypes in response to soil water deficit and to assess the potential of thermal imaging as a tool to monitor plant water status and stomatal aperture (stress monitoring).

Two independent field experiments were conducted combining thermal imaging, leaf gas exchange, leaf morphology and carbon isotope analysis. In Experiment I, we monitored plant water status and leaf gas exchange along the summer season in plants of Aragonez and Trincadeira subjected to different irrigation treatments. In Experiment II, we characterised the transpirational behaviour of five different grapevine genotypes (Trincadeira, Aragonez, Cabernet Sauvignon, Syrah and Touriga Nacional) growing in the field under regulated deficit irrigation.

\section{Materials and methods}

\section{Location and climate}

Two experiments were conducted at a commercial vineyard (Monte Seis Reis) located in Estremoz $\left(38^{\circ} 48^{\prime} \mathrm{N}, 7^{\circ} 29^{\prime} \mathrm{W}\right)$, South Portugal in 2006 and 2007. The climate is Mediterranean, with hot, dry summers and mild air temperatures with precipitation concentrated during autumn and winter (Fig. 1). When comparing the 2 years, 2006 was found to be the hottest with mean summer temperatures, $1.5-2^{\circ} \mathrm{C}$ higher than those measured in 2007 (Fig. 1; Table 1). The year 2006 was also characterised by lower precipitation in the winter and spring than in 2007 (Fig. 1). This may have contributed to a

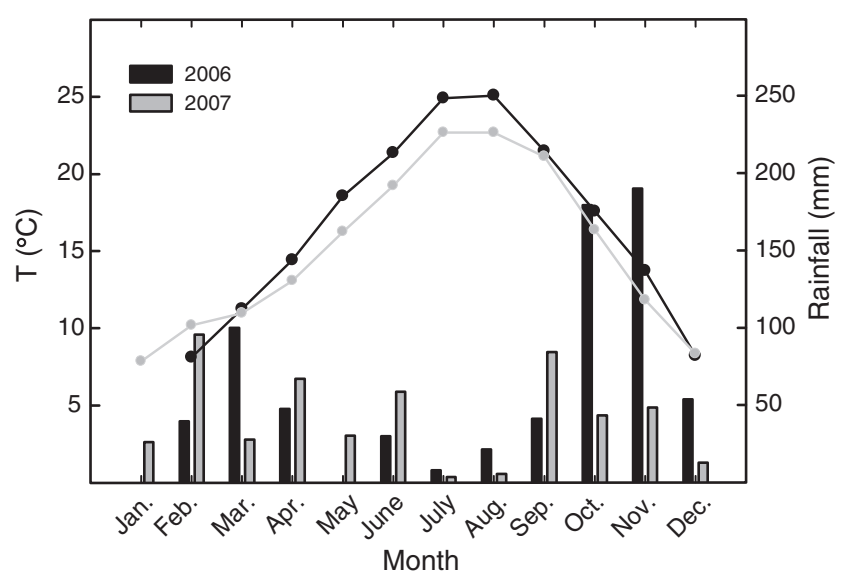

Fig. 1. Variation of the mean air temperature $(T$, lines) and precipitation (Rainfall, bars) measured for the years 2006 and 2007.

more severe summer drought stress experienced by plants in 2006 than in 2007.

Climate data on precipitation, solar radiation, air $\mathrm{RH}$, air temperature, potential evapotranspiration $\left(E T_{\mathrm{o}}\right)$ and wind speed were obtained from an automatic weather station located near the vineyard $\left(38^{\circ} 52^{\prime} \mathrm{N}, 07^{\circ} 31^{\prime} \mathrm{W}\right)$ (COTR 2007). Vapour pressure deficit (VPD) was calculated from measurements of ambient temperature and humidity and expresses the evaporative demand of the atmosphere.

The soil is derived from schist with a variable depth $(1.0-1.5 \mathrm{~m})$. Soil horizons present a silty clay loam texture with the following average characteristics: clay $34.2 \%$; silt $30.4 \%$; sand $35.4 \%$; organic matter $2.0 \%$; $\mathrm{pH}$ of 7.1 . The total soil available water, up to $1.0 \mathrm{~m}$ depth, was $124.2 \mathrm{~mm}$, determined as the difference between field capacity and permanent wilting point.

\section{Plant material}

In Experiment I, two grapevine (Vitis vinifera L.) varieties were studied: 'Aragonez' (syn. Tempranillo) (ARA) and 'Trincadeira' (TRI). In Experiment II, we compared five varieties: 'Touriga Nacional' (TOU); 'Aragonez' (ARA); 'Syrah' (SYR); 'Trincadeira' (TRI); and 'Cabernet Sauvignon' (CAB). All vines were 6-7 years old and were grafted on the rootstock 1103-P. They were planted at a density of 4000 plants ha $^{-1}$, with a spacing of $2.5 \times 1.0 \mathrm{~m}$. Vines were trained on a bilateral Royat Cordon system using a vertical shoot positioning with a

Table 1. Global radiation $\left(R_{\mathrm{G}}\right)$, mean air temperature $\left(T_{\text {mean }}\right)$, wind speed at $2 \mathrm{~m}$ above ground surface $\left(\mathrm{u}_{2 \mathrm{~m}}\right)$, vapour pressure deficit (VPD), reference evapotranspiration $\left(E T_{0}\right)$ measured at different dates of thermal imaging measurements conducted in Experiment I (2006) and in Experiment II (beginning of August 2006 and 2007)

Source: Centro Operativo e de Tecnologia de Regadio (COTR 2007)

\begin{tabular}{|c|c|c|c|c|c|}
\hline \multirow[t]{2}{*}{ Parameter } & \multicolumn{3}{|c|}{ Experiment I } & \multicolumn{2}{|c|}{ Experiment II } \\
\hline & 28-29 June 2006 & 1-2 August 2006 & 29-30 August 2006 & 8 August 2006 & 9 August 2007 \\
\hline$R_{\mathrm{G}}\left(\mathrm{MJ} \mathrm{m}^{-2}\right.$ day $\left.^{-1}\right)$ & $27.9-28.5$ & $25.3-26.0$ & $27.4-27.4$ & 24.7 & 25.0 \\
\hline$T_{\text {mean }}\left({ }^{\circ} \mathrm{C}\right)$ & $20.0-22.9$ & $23.6-25.0$ & $27.6-28.0$ & 28.4 & 26.9 \\
\hline $\mathrm{u}_{2 \mathrm{~m}}\left(\mathrm{~m} \mathrm{~s}^{-1}\right)$ & $1.2-1.1$ & $1.0-1.0$ & $1.1-1.0$ & 1.0 & 1.0 \\
\hline VPD $(\mathrm{kPa})$ & $0.85-1.16$ & $1.18-1.28$ & $2.19-2.42$ & 2.45 & 2.32 \\
\hline$E T_{\mathrm{o}}\left(\mathrm{mm} \mathrm{day}^{-1}\right)$ & $3.9-4.2$ & $4.1-4.3$ & $5.6-6.0$ & 5.2 & 4.6 \\
\hline
\end{tabular}


pair of movable wires and spur pruned. All vines were uniformly pruned to 12-14 nodes per vine. Vines from the varieties ARA and TRI were grown side by side. Plants of the remaining varieties were grown in nearby plots with similar sun exposure and soil characteristics. The standard cultural practices of the region were applied by keeping the natural soil cover during the season. Shoots were trimmed at $\sim 30 \mathrm{~cm}$ above the higher movable wire, once or twice between bloom and veraison.

\section{Irrigation treatments}

Experiment I was conducted during the summer of 2006. The vines of the varieties ARA and TRI were subjected to three irrigation treatments: well irrigated (WI, $80 \% E T_{\mathrm{c}}$ ), non-irrigated but rain fed (NI) and regulated deficit irrigation (RDI, $40 \% E T_{\mathrm{c}}$ ). Watering was applied according to crop evapotranspiration $\left(E T_{\mathrm{c}}\right)$ and soil water content. $E T_{\mathrm{c}}$ was estimated from the $E T_{\mathrm{o}}$, using the crop coefficients $\left(K_{\mathrm{c}}\right)$ proposed by the FAO (1998).

Experiment II was conducted during two consecutive summers: 2006 and 2007. The vines from the five varieties studied (ARA, TOU, SYR, TRIN and CAB) were grown under RDI (30-40\% $\left.E T_{\mathrm{c}}\right)$ conditions. In 2006, RDI was around $40 \% E T_{\mathrm{c}}$. RDI irrigation started on the 19 June and finished mid August (DOY=227). Irrigation amount was adjusted in both WI and RDI taking into consideration precipitation events (Fig. 1). By mid August a short interruption of irrigation occurred by a technical default in the WI treatment. In 2007, RDI irrigation started on the 26 June and was arrested on the 11 August. RDI was between 30-40\% of $E T_{\mathrm{c}}$ to adjust to the less stressful conditions compared with 2006. For details on the water applied (mm) see Table 2. Drip irrigation lines were positioned along plants' row and consisted of pressure compensating $2.5 \mathrm{~L} \mathrm{~h}^{-1}$ emitters at $1.0 \mathrm{~m}$ spacing, one per vine, positioned between two contiguous vines.

\section{Measurements}

\section{Soil and plant water status}

Soil water content was monitored with a capacitance probe (Diviner 2000TM; Sentek Environmental Technologies, Kent Town, SA, Australia). Predawn leaf water potential $\left(\Psi_{\mathrm{pd}}\right)$ was

Table 2. Amount of water applied $(\mathrm{mm})$ and fraction of transpirable soil water (FTSW, \%, measured at $1 \mathrm{~m}$ depth), on 1 August 2006 and on 6 August 2007) to plants of the different genotypes of the Experiment II, Aragonez (ARA), Trincadeira (TRI), Syrah (SYR), Cabernet (CAB) and Touriga Nacional (TOU) subjected to RDI conditions since 2006

\begin{tabular}{cccc}
\hline Year & $\begin{array}{c}\text { Vitis vinifera } \\
\text { genotype }\end{array}$ & $\begin{array}{c}\text { Water } \\
\text { applied (mm) }\end{array}$ & FTSW \\
\hline 2006 & TRI & 126 & 52 \\
& TOU & 145 & 47 \\
& CAB & 145 & 47 \\
& SYR & 121 & 29 \\
2007 & ARA & 86 & 40 \\
& TRI & 32 & 55 \\
& TOU & 28 & 57 \\
& CAB & 28 & 57 \\
& SYR & 36 & 43 \\
& ARA & 63 & 45 \\
\hline
\end{tabular}

measured at 0300-0400 hours solar time using a pressure chamber (Model 1000; PMS Instrument Co., Corvallis, OR).

In Experiment I, $\Psi_{\text {pd }}$ was measured periodically from the 29 June until the 1 September 2006. In Experiment II, $\Psi_{\text {pd }}$ was measured during the first 2 weeks of August in 2006 and 2007. Here, 4-6 plants located in three different rows were used and three leaves were harvested per plant.

\section{Canopy temperature and thermal indices}

In order to assess vines canopy temperature, we used in both experiments a thermal imager (IR Snapshot 525, Infrared Solutions, Minneapolis, MN), which consisted in a $120 \times 120$ pixel line scan imager operating in the wavebands $8-12 \mu \mathrm{m}$, with a noise equivalent temperature difference (NETD) of $0.1^{\circ} \mathrm{C}$ at $30^{\circ} \mathrm{C}$ and an accuracy of $2^{\circ} \mathrm{C}$ or $2 \%$ of reading. Infrared (IR) images were taken from the sunlit side of the canopy (Jones et al. 2002). Background temperature was determined as the temperature of a crumpled sheet of aluminium foil in a similar position to the leaves of interest with the emissivity set at 1.0 (Jones et al. 2002). Emissivity for measurements of grapevine leaves/canopies was set at 0.96 (Grant et al. 2006; Leinonen et al. 2006). Images were taken at a distance of $\sim 1-1.5 \mathrm{~m}$ from the canopy of interest resulting in an IR image representative of a surface of $0.25 \mathrm{~m}^{2}(0.05 \times 0.05 \mathrm{~m})$ of the canopy foliage. Visible digital images were taken immediately after infrared measurements to aid subsequent analysis of thermograms in the SnapView Pro software (Infrared Solutions), as previously described in literature (Grant et al. 2006; Leinonen et al. 2006). By using the IR image software, we have selected the sunlit portions of leaves on the basis of the correspondent visible images and we corrected them for spatial calibration drift by subtracting a correspondent reference image of an isothermal surface (the lens cap), as suggested in the literature (Jones et al. 2002; Grant et al. 2006). Aluminium markers were placed over the canopies of interest and within the thermal camera's field of view as means to geo-reference the visible and thermal images.

In Experiment I, canopy temperature of NI, WI, RDI vines of the varieties ARA and TRI was assessed over the summer of 2006. We measured plants in two consecutive days to shorten measurements duration and minimise errors related to the rise of temperature of the thermal imager or eventual drift of environmental conditions; thermal imaging measurements were done on the 28-29 June (DOY $=179-180$ ), on the $1-2$ August $(\mathrm{DOY}=213-214)$ and on the 29-30 August. $(\mathrm{DOY}=241-242)$. In Experiment I, thermal images were taken from four vines per irrigation treatment (two vines per day) in the morning (0900-1100 hours, in 2006) and in early afternoon (1330-1530 hours in 2006 and 2007). In Experiment II, we measured canopy temperature only at veraison (8 August 2006 and 9 August 2007) and in early afternoon. Here, 3-4 plants per variety were selected in different rows.

\section{Thermal indices}

To reduce meteorological interference in the interpretation of $T_{\text {leaf }}$ measurements in relation to stomatal opening, we have calculated two thermal indices: the index of stomatal conductance $\left(I_{\mathrm{G}}\right)$ and the crop water stress index (CWSI). The index $I_{\mathrm{G}}=\left(T_{\text {dry }}-T_{\text {leaf }}\right) /\left(T_{\text {leaf }}-T_{\text {wet }}\right)$, is theoretically proportional 
to stomatal conductance of water vapour (Jones et al. 2002). The CWSI $=\left(T_{\text {dry }}-T_{\text {leaf }}\right) /\left(T_{\text {dry }}-T_{\text {wet }}\right)$ (Idso 1982$)$ commonly varies between 0 and 1 . Values close to 0 indicate a fully transpiring leaf/crop (no stress) whereas values close to 1 indicate a non-transpiring leaf/crop (maximum stress). The $T_{\text {dry }}$ and $T_{\text {wet }}$ values used to estimate the thermal indices in Experiment I corresponded to the leaf temperatures of NI and WI plants, respectively, as previously suggested in the literature (Grant et al. 2006; Jones et al. 2009). NI and WI plants were measured just before measuring RDI vines.

\section{Individual leaf gas exchange and Chl a fluorescence}

In both experiments, we measured leaf stomatal conductance to water vapour $\left(g_{\mathrm{s}}\right)$ and net assimilation $\left(A_{\mathrm{n}}\right)$ immediately after thermal imaging measurements. We measured 3-4 light exposed leaves within the area of the canopy shown by the thermal camera. A total of 3-4 plants per genotype per treatment were used. Leaf gas exchange was determined with a portable infrared gasanalyser (Li-Cor 6400, Li-Cor, Lincoln, NE, USA) equipped with a transparent $6 \mathrm{~cm}^{2}$ leaf chamber, with uncontrolled block temperature and $\mathrm{CO}_{2}$, and air flow rate set at $500 \mu \mathrm{mol} \mathrm{s}{ }^{-1}$.

In Experiment II, we also generated light response curves of $A_{\mathrm{n}}$ for the five genotypes using the Li-Cor 6400 with a chamber 6400-02B (Li-Cor Inc.) equipped with a LED red/blue light source. The curves were obtained by measuring $A_{\mathrm{n}}$ at steadystate under different PPFDs (2000 to $0 \mu \mathrm{mol} \mathrm{m}^{-2} \mathrm{~s}^{-1}$ ), at constant air $\mathrm{CO}_{2}\left(360 \mu \mathrm{L} \mathrm{L}^{-1}\right)$, a block temperature set at $25^{\circ} \mathrm{C}$ and an air flow rate set at $500 \mu \mathrm{mol} \mathrm{s}{ }^{-1}$. Measurements were conducted between 0900 and 1300 hours on six plants per variety and one leaf per plant.

Dark adapted measurements of Chl $a$ fluorescence included ground state fluorescence $\left(F_{\mathrm{o}}\right)$, maximal fluorescence $\left(F_{\mathrm{m}}\right)$ and maximum quantum yield of the PSII system $\left(F_{\mathrm{v}} / F_{\mathrm{m}}=\left(F_{\mathrm{m}}-F_{\mathrm{o}}\right) /\right.$ $\left.F_{\mathrm{m}}\right)$. Chl $a$ fluorescence was measured in both experiments on 4 August 2006 at pre-dawn (0300-0400 hours solar time) with a Li-Cor 6400 equipped with a fluorometer (6400-40; Li-Cor Inc.).

\section{Leaf carbon isotope composition $\delta^{13} \mathrm{C}$}

At the end of August of 2006 and 2007, leaves were randomly harvested from six plants under study and oven-dried for 3 days at $70^{\circ} \mathrm{C}$. Six leaves were harvested per variety. The dry leaf samples were ground to a fine homogeneous powder and $1 \mathrm{mg}$ was used to determine carbon isotope composition $\left(\delta^{13} \mathrm{C} \%\right.$ ). Analysis was done using a Europa Scientific ANCA-SL Stable Isotope Analysis System (Europa Scientific Ltd, Crewe, UK). Carbon isotopic composition was expressed as:

$$
\delta^{13} \mathrm{C} \% o=\left(\left(R_{\mathrm{s}}-R_{\mathrm{b}}\right) / R_{\mathrm{b}}\right) \times 1000,
$$

where $R_{\mathrm{s}}$ is the ratio ${ }^{13} \mathrm{C} /{ }^{12} \mathrm{C}$ of the sample and $R_{\mathrm{b}}$ is the ${ }^{13} \mathrm{C} /{ }^{12} \mathrm{C}$ of the Pee Dee Belemnite standard.

\section{Leaf morphology and chlorophyll content}

The individual leaf area and dry weight and the specific leaf area (SLA) were determined in Experiment II. Leaves were randomly harvested from the intermediate part of the shoots (the 5th-8th leaf counting from the base). Individual leaf area was determined either with a leaf area meter (model WDIGC-2;
WinDIAS, Delta-T Devices, Cambridge, UK) or by digitalisation using the software 'Image J' (http://rsbweb.nih.gov/ij/, accessed July 2011). Dry weight was determined after drying leaves in the oven at $70^{\circ} \mathrm{C}$, for about 1 week. Chlorophyll ( $a$ and $b$ ) content was determined as described by de Souza et al. (2005).

Leaf stomatal density was quantified for leaves similar to the ones used in gas-exchange measurements. Here, 4-6 leaves were used per variety. From each leaf we took three small pieces and counted the number of stomata from three different fields of view. Nail-polish inprints were made by brushing the abaxial side of the leaf with nail-polish and further peeling the inprint with the help of a pair of forceps. Peels were mounted on a dry microscopical lamina and viewed under a light microscope. Images were acquired on a Leica (Wetzlar, Germany) DMRD microscope equipped with a metric ocular $(10 \times)$ and a $20 \times$ or $40 \times$ objective, using a COHU high performance CCD camera driven by Leica QFISH software.

\section{Statistical design and analyses}

The design of Experiment I was a randomised complete block design with three replications and the following irrigation treatments: non-irrigated but rain fed (NI), regulated deficit irrigation (RDI) and well irrigated (WI). Each replicate (plot) had three adjacent rows (two guard rows and a central for measurements) with 20 vines each. Means were subjected to analysis of variance and were separated by least significant difference (1.s.d.) $(P<0.05)$. In Experiment II, vines of five varieties grown in (five) non-randomised plots of the same commercial vineyard were used in 2006 and 2007 to assess for genotype differences in leaf temperature and stomatal conductance to water vapour in response to RDI conditions. Differences between means were assessed by one-way ANOVA $(P<0.05)$ performed using the statistical software SPSS (SPSS Inc., Chicago, IL, USA).

\section{Results}

Thermal imaging and plant water status monitoring (Experiment I)

\section{Climate parameters}

Meteorological conditions prevailing during the experimental period are presented in Fig. 1 and Table 1. Solar radiation varied between 25.3 and $28.5 \mathrm{MJ} \mathrm{m}^{-2}$ day $^{-1}$, indicating conditions of clear sky. VPD calculated from measurements of ambient temperature and $\mathrm{RH}$, (which express the evaporative demand of the atmosphere), showed fluctuations during the period of Experiment I, with the highest value being measured by the end of August (Table 1). Clear differences between the 2 years are apparent, with 2006 being hotter than 2007.

\section{Leafpredawn water potential $\left(\Psi_{p d}\right)$, leaftemperature $\left(\mathrm{T}_{\text {leaf }}\right)$ and individual leaf gas exchange}

The seasonal course of leaf water potential, leaf temperature assessed by thermal imaging ( $\left.T_{\text {leaf }}\right)$ and leaf gas exchange of the varieties ARA and TRI in Experiment I is presented in Fig. 2.

The $\Psi_{\mathrm{pd}}$ of the two varieties remained constant under WI conditions until veraison. After arresting irrigation on 2 September (DOY 245), plants of the variety ARA presented 
ARAGONEZ
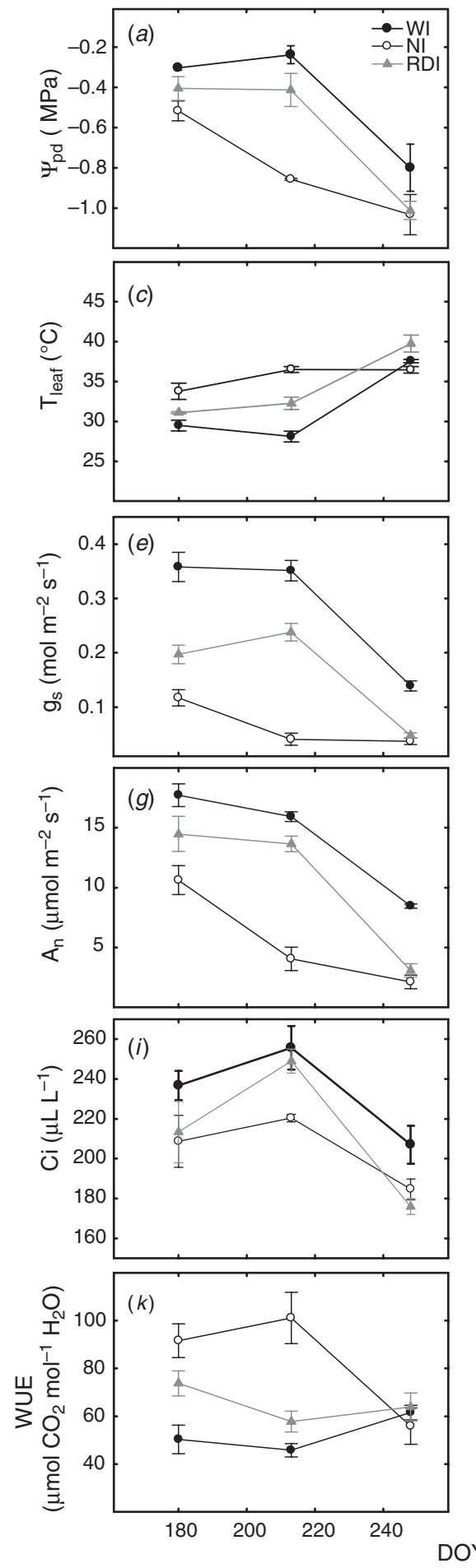

TRINCADEIRA
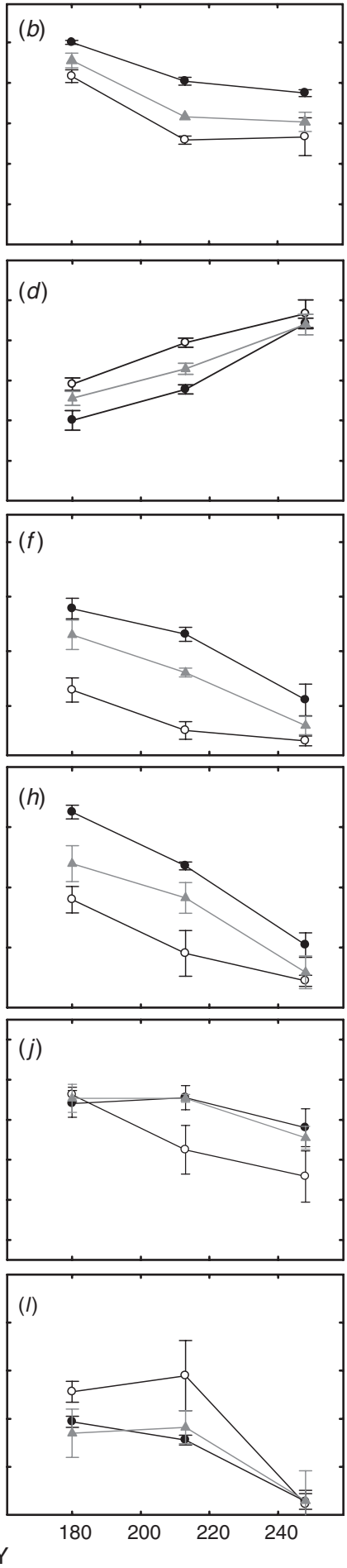

Fig. 2. Seasonal variation of Vitis vinifera $(a, b)$ leaf pre-dawn leaf water potential $\left(\Psi_{\mathrm{pd}}\right.$, $\mathrm{MPa}),(c, d)$ leaf temperature $\left(T_{\text {leaf }},{ }^{\circ} \mathrm{C}\right),(e, f)$ leaf stomatal conductance to water vapour $\left(g_{\mathrm{s}}, \mathrm{mol}^{-1} \mathrm{H}_{2} \mathrm{O} \mathrm{m}^{-2} \mathrm{~s}^{-1}\right),(g, h)$ net assimilation $\left(A_{\mathrm{n}}, \mu \mathrm{mol} \mathrm{CO} \mathrm{Cm}^{-2} \mathrm{~s}^{-1}\right),(i, j)$ internal $\mathrm{CO}_{2}$ concentration at the substomatal cavity $\left(C_{\mathrm{i}}, \mu \mathrm{L} \mathrm{L}^{-1}\right)$ and $(k, l)$ intrinsic water use efficiency (WUE ${ }_{\mathrm{i}}=A_{\mathrm{n}} / g_{\mathrm{s}}, \mu \mathrm{mol} \mathrm{CO} \mathrm{Col}^{-1} \mathrm{H}_{2} \mathrm{O}$ ) for the varieties Aragonez (ARA) and Trincadeira (TRI) measured in Experiment I, in 2006. Leaf temperature was determined at early afternoon by using thermal imaging and leaf gas exchange was determined with a portable gas exchange meter Li-Cor 6400 (see 'Materials and methods' for details). 
(a)

ARAGONEZ
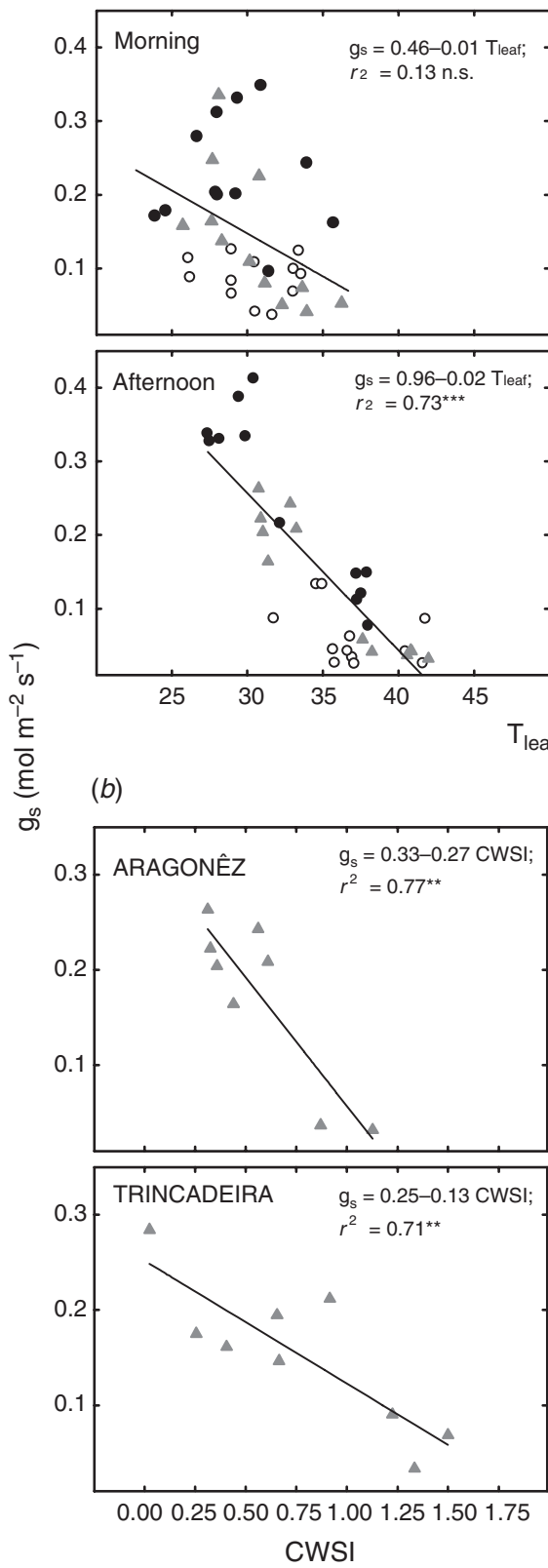

TRINCADEIRA
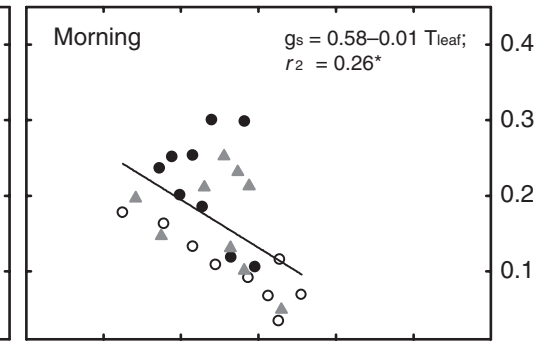

0.2

$-0.1$

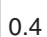

0.3

0.2

0.1

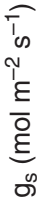
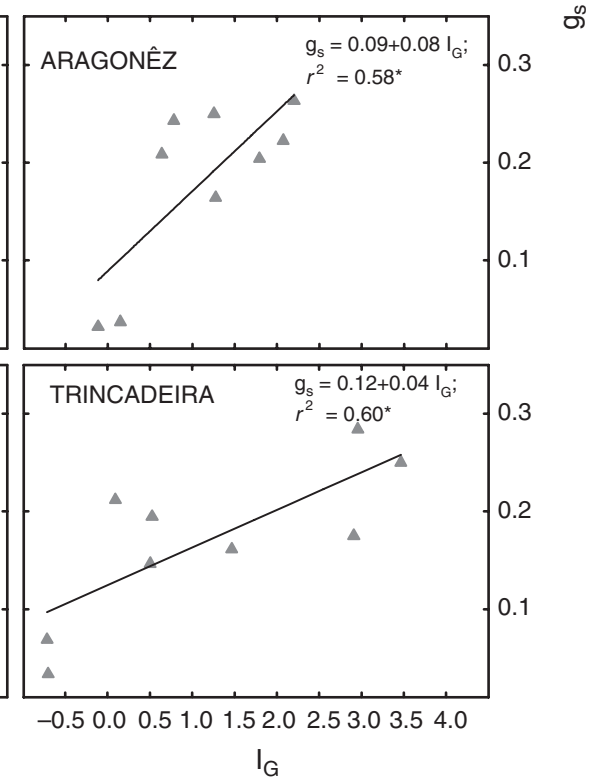

Fig. 3. (a) Relationship between Vitis vinifera leaf temperature assessed by thermal imaging $\left(T_{\text {leaf }}\right)$ at morning and early afternoon, and leaf stomatal conductance to water vapour $\left(g_{\mathrm{s}}, \mathrm{mol} \mathrm{H}_{2} \mathrm{O} \mathrm{m}^{-2} \mathrm{~s}^{-1}\right)$, for the varieties Aragonez and Trincadeira, grown under well irrigated conditions (WI) (•), non-irrigated but rain fed (NI) (O) and subjected to regulated deficit irrigation (RDI) (A). Data was collected during the summer of 2006 (28-29 June, 1-2 August and 29-30 August). The correlation was done for all points for the varieties Aragonez $(n=12)$ and Trincadeira $(n=9) ;(b)$ Relationship between the two thermal indices (CWSI and $\left.I_{\mathrm{G}}\right)$ and leaf stomatal conductance to water vapour $\left(g_{\mathrm{s}}, \mathrm{mol} \mathrm{H}_{2} \mathrm{O} \mathrm{m}^{-2} \mathrm{~s}^{-1}\right)$ measured at early afternoon (1300-1500 hours) during the summer, for plants of the varieties Aragonez and Trincadeira subjected to regulated deficit irrigation (RDI, $40 \% E T_{\mathrm{c}}$ ). The indices values derive from thermal imaging measurements conducted along the summer of 2006: 28-29 June, 1-2 August and 29-30 August. Significance levels are indicated: *, $P<0.05$; **, $P<0.01$; ***, $P<0.001$; n.s., non-significant. 
lower $\Psi_{\text {pd }}$ than TRI ( $-0.8 \mathrm{MPa}$ and $-0.4 \mathrm{MPa}$ for ARA and TRI respectively) (Fig. $2 a, b)$. NI vines presented a gradual decrease of $\Psi_{\mathrm{pd}}$ since the beginning of the observations on DOY 180 (Fig. 2a, b). Regulated deficit irrigation resulted in intermediate values of $\Psi_{\text {pd }}$ and $T_{\text {leaf }}$ compared with NI and WI vines in both varieties (Fig. $2 a-d$ ). Leaf temperature of NI plants was $\sim 2-4^{\circ} \mathrm{C}$ higher than in RDI and $4-8^{\circ} \mathrm{C}$ higher than in WI vines, in both ARA and TRI. This corresponds to a more pronounced reduction of $g_{\mathrm{s}}$ observed in NI plants (3-3.5 times lower than in WI plants and $\sim 2-3$ times lower than in RDI plants, until mid season) (Fig. 2e, $f$ ). The reduced $g_{\mathrm{s}}$ resulted in lower internal carbon dioxide concentration $\left(C_{\mathrm{i}}\right)$ values and net photosynthetic rates in NI plants and intermediate values in RDI vines than WI ones (Fig. $2 e-j$ ).

By the end of the season (DOY $=245), \Psi_{\mathrm{pd}}$ of plants from $\mathrm{NI}$ and RDI treatments were lower than those from WI vines. Similarly, $g_{\mathrm{s}}$ and $A_{\mathrm{n}}$ of NI and RDI vines were similar by the end of the season, but significantly lower than WI vines (Fig. $2 e-h$ ). The decrease observed in leaf water potential of WI plants in the last date of observation may be related with a short interruption of irrigation that occurred before mid August (Fig. 2a, $b$ ). RDI plants showed lower $\mathrm{WUE}_{\mathrm{i}}$ than NI plants until mid season, in particular in ARA (Fig. $2 k, l$ ).

In both varieties, the negative relationship between $T_{\text {leaf }}$ and $g_{\mathrm{s}}$ was significant in the afternoon $\left(r^{2}=0.73\right.$ and $r^{2}=0.74$, $P<0.001$, for ARA and TRI respectively) (Fig. $3 a$ ). In the morning, only TRI showed a statistically significant relationship between $T_{\text {leaf }}$ and $g_{\mathrm{s}}\left(r^{2}=0.26, P<0.05\right)$ (Fig. $3 a$ ).

The relationship between the thermal indexes, CWSI and $I_{\mathrm{G}}$, derived from thermal imaging measurements and leaf stomatal conductance to water vapour for the entire set of data is shown in Fig. $3 b$. There was an inverse relationship between the CWSI and $g_{\mathrm{s}}\left(r^{2}=0.77, P<0.01\right.$, for ARA and $r^{2}=0.71, P<0.01$ for TRI) and a positive relationship between $g_{\mathrm{s}}$ and the index $\mathrm{I}_{\mathrm{G}}$ $\left(r^{2}=0.58, P<0.05\right.$, for ARA and $r^{2}=0.60, P<0.05$ for TRI) (Fig. 3b).
Leaf temperature and characterisation of grapevine varieties (Experiment II)

\section{Climate parameters}

Meteorological conditions for Experiment II are shown in Table 1. Solar radiation measured in August 2006 and 2007 corresponded to conditions of clear sky and the average air temperature was $\sim 1.5^{\circ} \mathrm{C}$ higher in 2006 than in 2007 (Table 1). VPD values were higher in 2006 as well. Wind speed by the time of measurements was low in both years.

\section{Plant and soil water status, leaf temperature}

and individual leaf gas exchange

The lowest values of $\Psi_{\mathrm{pd}}$ measured at veraison were observed in 2006 (Table 3), which is attributed to the combined effect of a dryer spring and consequently less water available in the soil, or to higher average air temperatures and VPD at the time of measurements (Table 1). No significant differences among genotypes were found for the $\Psi_{\mathrm{pd}}$ in 2006. In 2007, there were differences between varieties but $\Psi_{\mathrm{pd}}$ values corresponded to the absence of water stress (Table 3).

Regarding leaf temperature, the highest values were measured in 2006 (more severe stress than in 2007) (Fig. 4; Table 3). In both years TOU vines had significantly lower leaf temperatures $\left(33.9 \pm 1.0^{\circ} \mathrm{C}\right.$ in 2006 and $29.5 \pm 1.2^{\circ} \mathrm{C}$ in 2007) than SYR $\left(36.9 \pm 0.2^{\circ} \mathrm{C}\right.$ in 2006 and $34.4 \pm 1.5^{\circ} \mathrm{C}$ in 2007) (Fig. 4). Leaf temperature of TRI was also significantly higher than TOU in 2006 but not in 2007. In turn, $T_{\text {leaf }}$ of ARA and CAB did not differ from TRI, SYR and TOU (Fig. 4).

SYR generally presented the lowest $g_{\mathrm{s}}$ values, whereas TOU showed the highest (Table 3), which is in line with the thermal imaging measurements.

Based on measurements of $g_{\mathrm{s}}$ and $A_{\mathrm{n}}$ SYR did not show a significantly higher $\mathrm{WUE}_{\mathrm{i}}$ compared with the other varieties (Table 3). However, data from the 'long-term WUE', given by $\delta^{13} \mathrm{C}$ measurements, showed that in 2006 the varieties ARA, TRI

Table 3. Leaf area (LA, $\mathrm{cm}^{2}$ ), specific leaf area (SLA, $\mathrm{cm}^{2} \mathrm{~g}^{-1}$ ), leaf stomatal density at abaxial side (SD abaxial, stomata $\mathrm{mm}^{-2}$ ), chlorophyll content (total Chl, $\left.\mathrm{mg} \mathrm{m}^{-2}\right)$, pre-dawn leaf water potential $\left(\Psi_{\mathrm{pd}}, \mathrm{MPa}\right)$, net assimilation rate $\left(A_{\mathrm{n}}, \mu \mathrm{mol} \mathrm{CO} \mathrm{C}_{2} \mathrm{~m}^{-2} \mathrm{~s}^{-1}\right)$, stomatal conductance to water vapour $\left(g_{\mathrm{s}}\right.$, mol $\left.\mathrm{H}_{2} \mathrm{O} \mathrm{m}^{-2} \mathrm{~s}^{-1}\right)$, intrinsic water use efficiency $\left(\mathrm{WUE}_{\mathrm{i}}=A_{\mathrm{n}} / g_{\mathrm{s}}, \mu \mathrm{mol} \mathrm{CO} \mathrm{CO}_{2} \mathrm{~mol}^{-1} \mathrm{H}_{2} \mathrm{O}\right)$ and maximum quantum yield of the PSII system $\left(F_{\mathrm{v}} / F_{\mathrm{m}}\right) \mathrm{measured}$ under dark conditions, at dawn (0300-0400 hours solar time) measured for individual leaves of the varieties Aragonez (ARA), Trincadeira (TRI), Syrah (SYR), Cabernet (CAB) and Touriga Nacional (TOU)

Measurements were taken in August 2006 and 2007. Values are means \pm s.e. $(n=6-8$ leaves). Significance levels are indicated: *, $P<0.05 ; * *, P<0.01$; ***, $P<0.001$; n.s., non-significant. Different letters within the same column indicate significant differences for each year of observation

\begin{tabular}{|c|c|c|c|c|c|c|c|c|c|c|}
\hline Year & $\begin{array}{c}\text { Vitis vinifera } \\
\text { variety }\end{array}$ & LA & SLA & SD abaxial & Total Chl & $\Psi_{\mathrm{pd}}$ & $A_{\mathrm{n}}$ & $g_{\mathrm{s}}$ & $\mathrm{WUE}_{\mathrm{i}}$ & $F_{\mathrm{v}} / F_{\mathrm{m}}$ \\
\hline \multirow[t]{6}{*}{2006} & ARA & $249 \pm 15 a$ & $113 \pm 7$ & $124 \pm 5 \mathrm{ab}$ & $244 \pm 19 a$ & $-0.58 \pm 0.05$ & $9.9 \pm 1.3 \mathrm{ab}$ & $0.086 \pm 0.008 \mathrm{ab}$ & $123 \pm 22$ & $0.819 \pm 0.005$ \\
\hline & TRI & $218 \pm 16 a$ & $113 \pm 9$ & $116 \pm 5 \mathrm{ab}$ & $222 \pm 12 a$ & $-0.56 \pm 0.04$ & $8.6 \pm 1.3 \mathrm{ab}$ & $0.073 \pm 0.007 b$ & $116 \pm 14$ & $0.827 \pm 0.004$ \\
\hline & SYR & $183 \pm 10 \mathrm{ab}$ & $114 \pm 7$ & $106 \pm 6 b$ & $225 \pm 17 \mathrm{ab}$ & $-0.55 \pm 0.02$ & $5.6 \pm 1.2 b$ & $0.046 \pm 0.006 \mathrm{c}$ & $123 \pm 26$ & $0.817 \pm 0.004$ \\
\hline & $\mathrm{CAB}$ & $154 \pm 6 b$ & $118 \pm 10$ & $131 \pm 6 a$ & $189 \pm 8 b$ & $-0.54 \pm 0.02$ & $10.3 \pm 1.1 \mathrm{ab}$ & $0.132 \pm 0.019 a$ & $91 \pm 18$ & $0.803 \pm 0.003$ \\
\hline & TOU & $140 \pm 12 b$ & $112 \pm 4$ & $120 \pm 6 a b$ & $232 \pm 9 \mathrm{ab}$ & $-0.48 \pm 0.03$ & $12.3 \pm 0.8 \mathrm{a}$ & $0.145 \pm 0.017 \mathrm{a}$ & $92 \pm 14$ & $0.811 \pm 0.005$ \\
\hline & & $* * *$ & n.s. & $*$ & * & n.s. & $* * *$ & $* * *$ & n.s. & n.s. \\
\hline \multirow[t]{6}{*}{2007} & ARA & $297 \pm 12 \mathrm{a}$ & $126 \pm 4 b$ & - & - & $-0.25 \pm 0.01 b$ & $10.7 \pm 0.9$ & $0.160 \pm 0.008 \mathrm{ab}$ & $68 \pm 4 a b$ & - \\
\hline & TRI & $249 \pm 20 b$ & $135 \pm 7 \mathrm{ab}$ & - & - & $-0.10 \pm 0.06 \mathrm{a}$ & $10.3 \pm 1.8$ & $0.208 \pm 0.065 \mathrm{ab}$ & $57 \pm 10 \mathrm{ab}$ & - \\
\hline & SYR & $231 \pm 10 b$ & $125 \pm 3 b$ & - & - & $-0.19 \pm 0.02 \mathrm{ab}$ & $9.3 \pm 0.3$ & $0.125 \pm 0.015 b$ & $71 \pm 4 a$ & - \\
\hline & $\mathrm{CAB}$ & $189 \pm 8 c$ & $142 \pm 4 a$ & - & - & $-0.21 \pm 0.07 \mathrm{ab}$ & $11.9 \pm 0.6$ & $0.216 \pm 0.008 \mathrm{ab}$ & $56 \pm 1 \mathrm{ab}$ & - \\
\hline & TOU & $171 \pm 9 c$ & $140 \pm 5 a$ & - & - & $-0.10 \pm 0.02 \mathrm{a}$ & $12.4 \pm 0.5$ & $0.258 \pm 0.043 a$ & $51 \pm 6 b$ & - \\
\hline & & $* * *$ & * & - & - & $*$ & n.s. & $*$ & $*$ & - \\
\hline
\end{tabular}




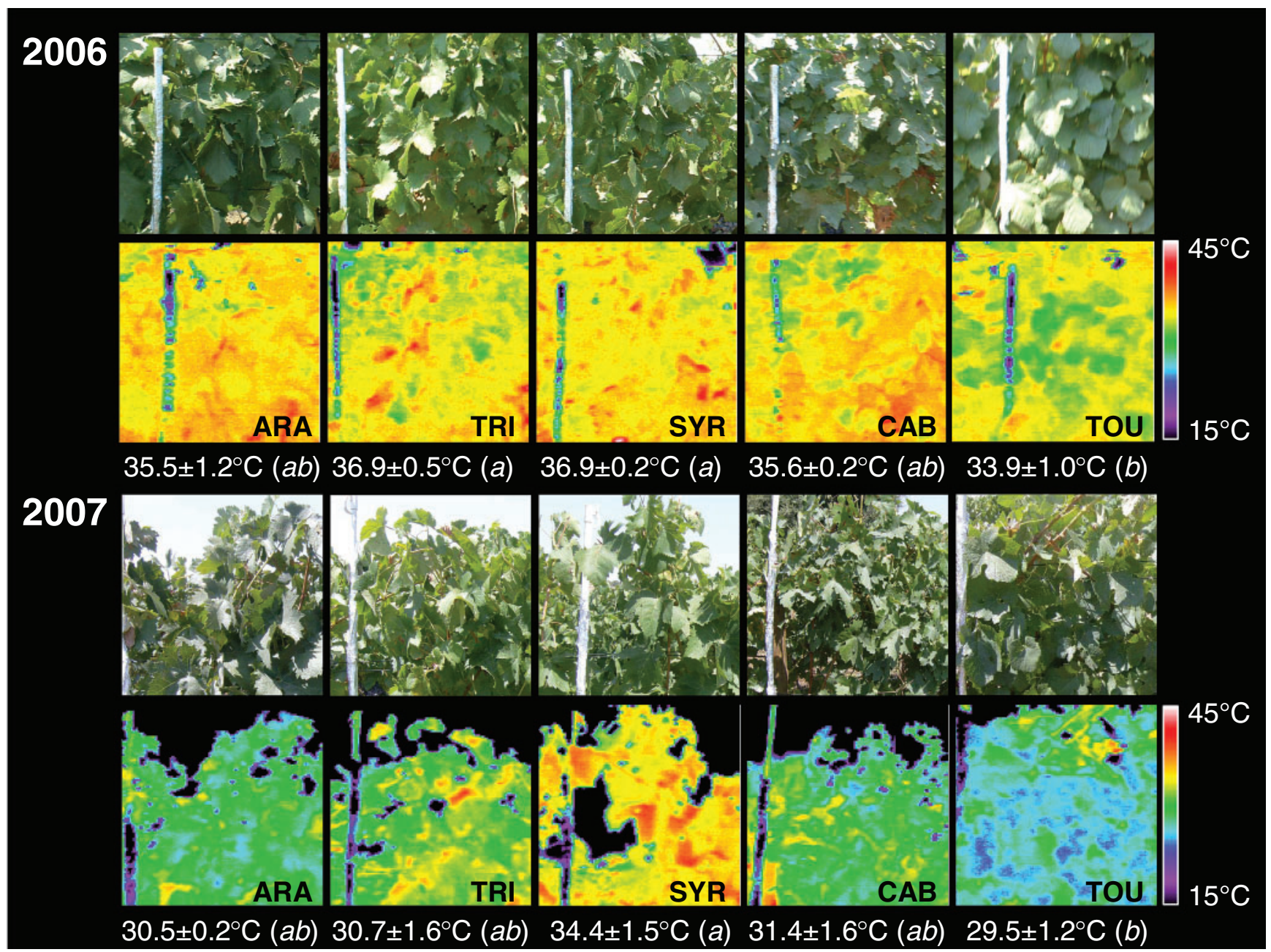

Fig. 4. Visible and false coloured infrared images of the canopies of Vitis vinifera Aragonez (ARA), Trincadeira (TRI), Syrah (SYR), Cabernet (CAB) and Touriga Nacional (TOU), measured at early afternoon (1300-1530 hours) at beginning of August of 2006 and 2007. Images were taken on 8 August 2006 (air $T_{\max }=38.2^{\circ} \mathrm{C}$, air $\mathrm{RH}_{\min }=18.2 \%$ ) and on 9 August 2007 (air $T_{\max }=36.8^{\circ} \mathrm{C}$, air $\mathrm{RH}_{\min }=13 \%$ ). Values are averages \pm s.e. calculated for the sunlit side of the canopy ( $n=3-4$ plants). Aluminium markers were used to assist selection of leaves of interest in the infrared images. Different letters indicate significant differences between varieties $(P<0.05)$, within the same year.

and SYR were more efficient in water use than TOU and CAB (Fig. 5). In 2007, with less stress, such differences were less apparent. Nevertheless, TOU had again a significantly lower $\delta^{13} \mathrm{C}$ than the remaining varieties (Fig. 5). SYR, in turn, showed one of the highest values of $\delta^{13} \mathrm{C}$, although not significantly different from ARA, TRI or CAB.

$F_{\mathrm{v}} / F_{\mathrm{m}}$ values were around 0.8 in all varieties indicating the absence of photoinhibition by the time of measurements (August). However, we have found differences in leaf $\mathrm{Chl}$ content among the five varieties in 2006, the more stressful year of Experiment II (Table 3).

\section{Leaf morphology}

The varieties TOU and $\mathrm{CAB}$ presented the lowest individual leaf area but no differences were observed in SLA (Table 3). The individual leaf area measured in 2006 (severe stress) was significantly smaller than that of 2007 (mild water stress), in particular for varieties with larger individual leaf area like ARA and TRI (Table 3), which suggests an adaptation response to water stress. In turn, SLA was higher in 2007 than in 2006 (Table 3). The number of stomata on the abaxial side of leaves was highest in CAB but with statistically significant differences only in relation to SYR. ARA, TOU and TRI did not differ from SYR or CAB (Table 3). However, the variation observed in stomatal density did not parallel the variation observed for stomatal conductance (Table 3).

\section{Discussion}

Thermal imaging appropriately monitored plant water status and therefore drought stress, in field conditions. Significant temperature differences measured with thermal imaging were detected between plants under different irrigation regimes and consequently different water status. This is in line with previous findings for grapevine (Jones et al. 2002; Grant et al. 2007; Möller 


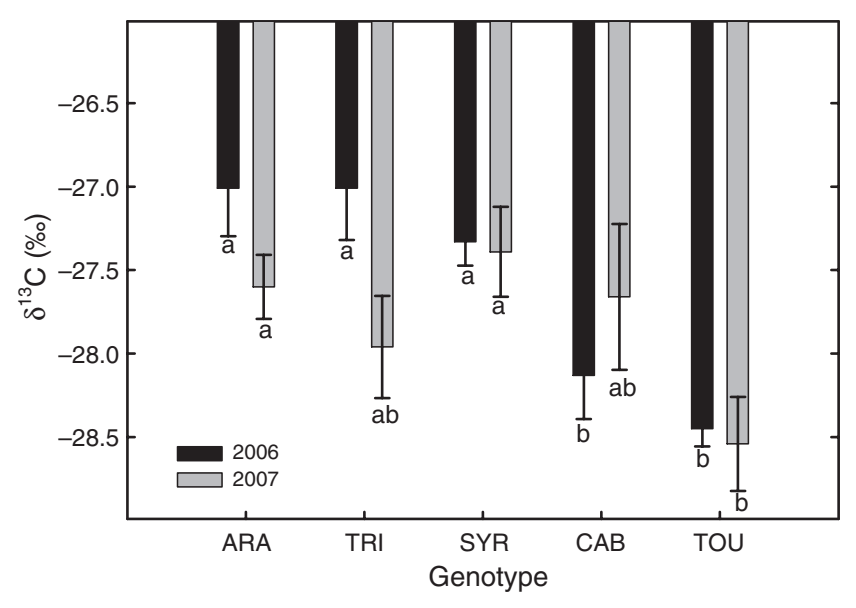

Fig. 5. Carbon isotope composition $\left(\delta^{13} \mathrm{C} \%\right.$ ) measured for leaves of the five Vitis vinifera varieties Aragonez (ARA), Trincadeira (TRI), Syrah (SYR), Cabernet (CAB) and Touriga Nacional (TOU). Measurements were done on the summer season of 2006 (high stress, black bars) and 2007 (moderate stress, grey bars).Values are means \pm s.e. ( $n=5-6$ leaves). Different letters indicate significant differences between varieties $(P<0.05)$, within the same year.

et al. 2007). Plants of the varieties ARA and TRI subjected to severe and mild water stress by application of NI and RDI strategies respectively, showed leaf temperatures $\sim 2.5-5^{\circ} \mathrm{C}$ higher than well irrigated vines. This was directly related to moderate to severe reduction of stomatal conductance to water vapour in RDI and NI vines and consequently to decreased transpiration and thus decreased 'evaporative cooling'. However, the negative relationship between leaf temperature and $g_{\mathrm{s}}$ was only significant at early afternoon (Fig. 3), suggesting that thermal imaging measurements are more sensitive at that time of the day as maximum differences between stressed and unstressed plants will be seen. This is in line with previous literature stating that sensitivity of thermal imaging to estimate leaf transpiration increases with higher air temperature, leaf-to-air vapour pressure deficit and radiation (Jones 1999).

The comparison of the five varieties in Experiment II (Fig. 4; Table 3) on the basis of thermal imaging and leaf gas-exchange measurements showed that for identical, or very close leaf water potential at pre-dawn (Table 3), leaf temperature varied with the variety (Fig. 4), which was related to different regulation of transpiration rates by stomata.

This shows that in addition to the monitoring of plant water status the use of thermal imaging to characterise canopy temperature has fundamental importance to properly assess plant condition, namely the regulation of stomata in different varieties.

The relationship between $g_{\mathrm{s}}$ and CWSI in our study confirms that this index is linked to stomatal regulation via its effect on crop energy balance. In general, CWSI values should be within a range from 0 to 1 (Möller et al. 2007). However, our results include values slightly above 1 such as reported by other authors for grapevine (Grant et al. 2007; Zia et al. 2009). This may be due to the fact that the plants used to determine $T_{\text {wet }}$ were not fully irrigated but solely well irrigated. Consequently, we may expect that the $T_{\text {wet }}$ values measured on a well irrigated plant will be higher than those of a fully irrigated vine, resulting in higher values of CWSI (larger than 1).

Measurements of leaf stomatal density showed that differences in $g_{s}$ between varieties are not correlated with the number of stomata at the abaxial side of leaves. $\mathrm{CAB}$ showed a significant higher number at the abaxial side of leaves but no correlation with $g_{\mathrm{s}}$ seems to exist. The absence of such correlation has also been reported in other varieties of grapevine grown in field conditions (Rogiers et al. 2009).

The values of maximum quantum yield $\left(F_{\mathrm{v}} / F_{\mathrm{m}}\right)$ were $\sim 0.8$, in Experiment I (data not shown) and Experiment II and even in 2006 when stress was more severe (Table 3). This supports the idea that the photochemical apparatus of grapevine is highly resistant to water stress (Flexas et al. 1999; Maroco et al. 2002) and suggests that the differences in net assimilation rates among varieties are not attributed to photoinhibition but rather to diffusive limitations, in particular stomatal related. Further, $g_{\mathrm{s}}$ has been considered the major determining factor of leaf photosynthesis under mild and moderate water stress (Chaves 1991; Cornic 2000; Flexas et al.2004). This is also in line with the seasonal courses of leaf gas exchange observed in Experiment I (Fig. $2 e-h$ ) where $g_{\mathrm{s}}$ and $A_{\mathrm{n}}$ varied in parallel, emphasising the role of stomatal regulation in grapevine photosynthesis (Chaves et al. 1987, 2010; Flexas et al. 1999; Moutinho-Pereira et al. 2004).

In both years of Experiment II (2006 and 2007) SYR presented the lowest $g_{\mathrm{s}}$ and $A_{\mathrm{n}}$ at different irradiances under similar leaf water potential values (data not shown).

Differences among genotypes may be related to different hormonal regulation of stomata and eventually to hydraulic differences (Schultz 2003; Lovisolo et al. 2010). Moreover, the size of the canopy leading to different velocities in dehydration may also play a role in explaining differences between the varieties (Rogiers et al. 2009).

Our results from leaf temperature and gas exchange suggest that the variety TOU, due to its higher capacity of heat dissipation via evaporative cooling (larger $g_{\mathrm{s}}$ and lower $T_{\text {leaf }}$ ) could be well adapted to warmer climate conditions when water is not dramatically reduced or under irrigated viticulture. However, if we consider WUE as selective criterion, which remains disputable, this could be a hindrance for TOU. In contrast, SYR although more efficient in terms of water use showed limitations in heat dissipation due to its reduced $g_{\mathrm{s}}$, which can favour the occurrence of leaf sun burn under conditions of heat stress and drought.

Irrigation is an efficient way to improve plant water status and decrease leaf temperature of grapevine plants under hot and dry conditions and is being used in Mediterranean vineyards. Nevertheless, genotypes show variation in their response to soil water deficits and in their capacity transpire and loose heat via evaporative cooling that has to be taken into account.

Therefore, the full characterisation of grapevine genotypes in terms of leaf gas-exchange characteristics, stomatal regulation and leaf temperature in response to mild to severe water stress is very important for breeding against drought. This becomes especially relevant in the context of the ongoing climate changes that may increase the incidence of drought and high temperature stresses in the Mediterranean area (Chaves et al. 
2010; Schultz and Stoll 2010). Our results demonstrate the possibility of using thermal imaging as a means to characterise transpirational behaviour of grapevine genotypes, which opens up the possibility of using the technique in the selection and management of varieties under different conditions of water availability.

\section{Acknowledgements}

MF Ortuño was granted a Postdoctoral research fellowship from the Spanish Ministry of Education and JM Costa was supported by a post-doc fellowship granted by Fundação para a Ciência e Tecnologia (ref. SFRH/BPD/34429/ 2006). The project POCI/AGR/59079/04, EU-WATERWEB, PEst-OE/EQB/ LA0004/2011 and GrapeBerryFactory (PTDC/AGR-ALI/100636/2008) supported part of the project. We acknowledge as well the Monte Seis Reis (Estremoz, Portugal) for providing a large set of facilities and to Jean François Selfslagh and Manuela Saraiva for English corrections.

\section{References}

Alchanatis V, Cohen Y, Cohen S, Möller M, Sprinstin M, Meron M, Tsipris J, Saranga Y, Sela E (2010) Evaluation of different approaches for estimating and mapping crop water status in cotton with thermal imaging. Precision Agriculture 11, 27-41. doi:10.1007/s11119-0099111-7

Araus JL, Slafer GA, Royo C, Serret MD (2008) Breeding for yield potential and stress adaptation in cereals. Critical Reviews in Plant Sciences 27, 377-412. doi:10.1080/07352680802467736

Ben-Gal A, Agam N, Alchanatis V, Cohen Y, Yermiyahu U, Zipori I, Presnov E, Sprintsin M, Dag A (2009) Evaluating water stress in irrigated olives: correlation of soil water status, tree water status, and thermal imagery. Irrigation Science 27, 367-376. doi:10.1007/s00271-009-0150-7

Bota J, Flexas J, Medrano H (2001) Genetic variability of photosynthesis and water use in Balearic grapevine cultivars. Annals of Applied Biology 138, 353-361. doi:10.1111/j.1744-7348.2001.tb00120.x

Chaerle L, Van der Straeten D (2000) Imaging techniques and the early detection of plant stress. Trends in Plant Science 5, 495-501. doi:10.1016/ S1360-1385(00)01781-7

Chaves MM (1991) Effects of water deficits on carbon assimilation. Journal of Experimental Botany 42, 1-16. doi:10.1093/jxb/42.1.1

Chaves MM, Rodrigues ML (1987) Photosynthesis and water relations of grapevines growing in Portugal response to environmental factors. In 'Plant response to stress - functional analysis in Mediterranean ecosystems'. (Eds JD Tenhunen, FM Catarino, OL Lange, WC Oechel) pp. 379-390. (Springer-Verlag: Berlin)

Chaves MM, Tenhunen JD, Harley P, Lange OL (1987) Gas exchange studies in two Portuguese grapevine cultivars. Physiologia Plantarum 70, 639-647. doi:10.1111/j.1399-3054.1987.tb04318.x

Chaves MM, Santos TP, Souza CR, Ortuno MF, Rodrigues ML, Lopes CM, Maroco JP, Pereira JS (2007) Deficit irrigation in grapevine improves water-use efficiency while controlling vigour and production quality. Annals of Applied Biology 150, 237-252. doi:10.1111/j.1744-7348. 2006.00123.x

Chaves MM, Zarrouk O, Francisco R, Costa JM, Santos T, Regalado AP, Rodrigues ML, Lopes CM (2010) Grapevine under deficit irrigation hints from physiological and molecular data. Annals of Botany 105, 661-676. doi:10.1093/aob/mcq030

Cifre J, Bota J, Escalona JM, Medrano H, Flexas J (2005) Physiological tools for irrigation scheduling in grapevine (Vitis vinifera L.). An open gate to improve water-use efficiency? Agriculture Ecosystems \& Environment 106, 159-170. doi:10.1016/j.agee.2004.10.005

Cornic G (2000) Drought stress inhibits photosynthesis by decreasing stomatal aperture - not affecting ATP synthesis. Trends in Plant Science 5, 187-188. doi:10.1016/S1360-1385(00)01625-3
Costa JM, Ortuño MF, Chaves MM (2007) Deficit irrigation as a strategy to save water: physiology and potential application to horticulture. Journal of Integrative Plant Biology 49, 1421-1434. doi:10.1111/j.1672-9072. 2007.00556.x

Costa JM, Grant OM, Chaves MM (2010) Use of thermal imaging in viticulture: current application and future prospects. In 'Methodologies and results in grapevine research'. (Eds S Delrot, H Medrano, E Or, L Bavaresco, S Grando) pp. 135-150. (Springer: Dordrecht, The Netherlands)

COTR (2007) Centro Operativo e de Tecnologia de Regadio. Available at http://www.cotr.pt [Verified 9 February 2012]

de Souza CR, Maroco JP, Santos TP, Rodrigues ML, Lopes C, Pereira JS, Chaves MM (2005) Control of stomatal aperture and carbon uptake by deficit irrigation in two grapevine cultivars. Agriculture Ecosystems \& Environment 106, 261-274. doi:10.1016/j.agee.2004.10.014

Escalona JM, Flexas J, Medrano H (1999) Stomatal and non-stomatal limitations of photosynthesis under water stress in field-grown grapevines. Australian Journal of Plant Physiology 26, 421-433. doi:10.1071/PP99019

FAO (1998) Crop evapotranspiration. (Eds RG Allen, LS Pereira, D Raes, M Smith). Irrigation and Drainage, Paper No. 56, FAO, Rome.

Flexas J, Escalona JM, Medrano H (1999) Water stress induces different levels of photosynthesis and electron transport rate regulation in grapevines. Plant, Cell \& Environment 22, 39-48. doi:10.1046/j.13653040.1999.00371.x

Flexas J, Bota J, Escalona JM, Sampol B, Medrano H (2002) Effects of drought on photosynthesis in grapevines under field conditions. An evaluation of stomatal and mesophyll limitations. Functional Plant Biology 29, 461-471. doi:10.1071/PP01119

Flexas J, Bota J, Loreto F, Cornic G, Sharkey TD (2004) Diffusive and metabolic limitations to photosynthesis under drought and salinity in $\mathrm{C}_{3}$ plants. Plant Biology 6, 269-279. doi:10.1055/s-2004-820867

Flexas J, Galmés J, Gallé A, Gulias J, Pou A, Ribas-Carbo A, Tomás A, Medrano H (2010) Improving water use efficiency in grapevines: potential physiological targets for biotechnological improvement. Australian Journal of Grape and Wine Research 16, 106-121. doi:10.1111/j.1755-0238.2009.00057.x

García-Tejero IF, Durán-Zuazo VH, Muriel-Fernández JL, JiménezBocanegra JA (2011) Linking canopy temperature and trunk diameter fluctuations with other physiological water status tools for water stress management in citrus orchards. Functional Plant Biology 38, 106-117. doi:10.1071/FP10202

Girona J, Mata M, del Campo J, Arbones A, Bartra E, Marsal J (2006) The use of midday leaf water potential for scheduling deficit irrigation in vineyards. Irrigation Science 24, 115-127. doi:10.1007/s00271-0050015-7

Grant OM, Chaves MM, Jones HG (2006) Optimizing thermal imaging as a technique for detecting stomatal closure induced by drought stress under greenhouse conditions. Physiologia Plantarum 127, 507-518. doi:10.1111/j.1399-3054.2006.00686.x

Grant OM, Tronina L, Jones HG, Chaves MM (2007) Exploring thermal imaging variables for the detection of stress responses in grapevine under different irrigation regimes. Journal of Experimental Botany $\mathbf{5 8}$, 815-825. doi:10.1093/jxb/erl153

Grant OM, Davies MJ, James CM, Johnson AW, Leinonen I, Simpson DW (2012) Thermal imaging and carbon isotope composition indicate variation amongst strawberry (Fragaria $\times$ ananassa) cultivars in stomatal conductance and water use efficiency. Environmental and Experimental Botany 76, 7-15. doi:10.1016/j.envexpbot.2011.09.013

Hirayama M, Wada Y, Nemoto H (2006) Estimation of drought tolerance based on leaf temperature in upland rice breeding. Breeding Science 56, 47-54. doi: $10.1270 /$ jsbbs. 56.47

Idso SB (1982) Non-water-stressed baselines - a key to measuring and interpreting plant water stress. Agricultural Meteorology 27, 59-70. doi:10.1016/0002-1571(82)90020-6 
James RA, von Caemmerer S, Condon AG, Zwart AB, Munns R (2008) Genetic variation in tolerance to the osmotic stress component of salinity stress in durum wheat. Functional Plant Biology 35, 111-123. doi:10.1071/FP07234

Jones HG (1999) Use of thermography for quantitative studies of spatial and temporal variation of stomatal conductance over leaf surfaces. Plant, Cell \& Environment 22, 1043-1055. doi:10.1046/j.1365-3040.1999.00468.x Jones HG (2004) Application of thermal imaging and infrared sensing in plant physiology and ecophysiology. Advances in Botanical Research 41, 107-163. doi:10.1016/S0065-2296(04)41003-9

Jones HG, Stoll M, Santos T, Sousa C, Chaves MM, Grant OM (2002) Use of infra-red thermography for monitoring stomatal closure in the field: application to grapevine. Journal of Experimental Botany 53, 2249-2260. doi:10.1093/jxb/erf083

Jones HG, Serraj R, Loveys BR, Xiong L, Wheaton A, Price AH (2009) Thermal infrared imaging of crop canopies for the remote diagnosis and quantification of plant responses to water stress in the field. Functional Plant Biology 36, 978-989. doi:10.1071/FP09123

Kaplan H (2007) 'Practical applications of infrared thermal sensing and imaging equipment.' 3rd edn. (SPIE Press: Washington)

Kashiwagi J, Krishnamurthy L, Upadhyaya HD, Gaur PM (2008) Rapid screening technique for canopy temperature status and its relevance to drought tolerance improvement in chickpea. Journal of SAT Agricultural Research 6, 1-4.

Leinonen I, Grant OM, Tagliavia CPP, Chaves MM, Jones HG (2006) Estimating stomatal conductance with thermal imagery. Plant, Cell \& Environment 29, 1508-1518. doi:10.1111/j.1365-3040.2006.01528.x

Lovisolo C, Perrone I, Carra A, Ferrandino A, Flexas J, Medrano H, Schubert A (2010) Drought-induced changes in development and function of grapevine (Vitis spp.) organs and in their hydraulic and non hydraulic interactions at the whole plant level: a physiological and molecular update. Functional Plant Biology 37, 98-116. doi:10.1071/FP09191

Maroco JP, Rodrigues ML, Lopes C, Chaves MM (2002) Limitations to leaf photosynthesis in field-grown grapevine under drought - metabolic and modelling approaches. Functional Plant Biology 29, 451-459. doi:10.1071/PP01040

Medrano H, Escalona JM, Cifre J, Bota J, Flexas J (2003) A ten-year study on the physiology of two Spanish grapevine varieties under field conditions: effects of water availability from leaf photosynthesis to grape yield and quality. Functional Plant Biology 30, 607-619. doi:10.1071/FP02110

Merlot S, Mustilli AC, Genty B, North H, Lefebvre V, Sotta B, Vavasseur A, Giraudat J (2002) Use of infrared thermal imaging to isolate Arabidopsis mutants defective in stomatal regulation. The Plant Journal 30, 601-609. doi:10.1046/j.1365-313X.2002.01322.x
Merlot S, Leonhardt N, Fenzi F, Valon C, Costa M, Piette L, Vavasseur A, Genty B, Boivin K, Müller A, Giraudat J, Leung J (2007) Constitutive activation of a plasma membrane $\mathrm{H}^{+}$-ATPase prevents abscisic acidmediated stomatal closure. EMBO Journal 26, 3216-3226. doi:10.1038/ sj.emboj. 7601750

Möller M, Alchanatis V, Cohen Y, Meron M, Tsipris J, Naor A, Ostrovsky V, Sprintsin M, Cohen S (2007) Use of thermal and visible imagery for estimating crop water status of irrigated grapevine. Journal of Experimental Botany 58, 827-838. doi:10.1093/jxb/erl115

Moutinho-Pereira JM, Correia CM, Gonçalves BM, Bacelar EA, TorresPereira JM (2004) Leaf gas exchange and water relations of grapevines grown in three different conditions. Photosynthetica 42, 81-86. doi:10.1023/B:PHOT.0000040573.09614.1d

Nilsson HE (1995) Remote sensing and image analysis in plant pathology. Annual Review of Phytopathology 33, 489-528. doi:10.1146/annurev. py.33.090195.002421

Raskin I, Ladyman JAR (1988) Isolation and characterization of a barley mutant with abscisic acid-insensitive stomata. Planta 173, 73-78. doi:10.1007/BF00394490

Rogiers SY, Greer DH, Hutton RJ, Landsberg JJ (2009) Does night-time transpiration contribute to anisohydric behaviour in a Vitis vinifera cultivar? Journal of Experimental Botany 60, 3751-3763. doi:10.1093/ jxb/erp217

Schultz HR (2003) Differences in hydraulic archicteture account for near isohydric and anisohydric behaviour of two field-grown Vitis vinifera L. varieties during drought. Plant, Cell \& Environment 26, 1393-1405. doi:10.1046/j.1365-3040.2003.01064.x

Schultz HR, Stoll M (2010) Some critical issues in environmental physiology of grapevines: future challenges and current limitations. Australian Journal of Grape and Wine Research 16, 4-24. doi:10.1111/j.17550238.2009.00074.x

Sirault XRR, James RA, Furbank RT (2009) A new screening method for osmotic component of salinity tolerance in cereals using infrared thermography. Functional Plant Biology 36, 970-977. doi:10.1071/ FP09182

Zia S, Spohrer K, Merkt N, Wenyong D, He X, Muller J (2009) Non invasive water status detection in grapevine. International Journal of Agricultural and Biological Engineering 2, 46-54. 